\title{
MANAJEMEN STRES DALAM PERSPEKTIF TASAWUF
}

\author{
Sugianto \\ IAI An-Nur Lampung \\ sugiantoalfaruqi3@gmail.com
}

\begin{abstract}
Abstrak
Kemampuan menyesuaikan diri dan mengontrol emosi dalam menyikapi berbagai problema kehidupan menjadikan manusia rentan pada gangguan mental seperti stres, cemas dan gelisah. Kemajuan sains dan teknologi pada masyarakat modern dan munculnya pemahaman the death of god membuat manusia semakin jauh dari transedental keagamaan dan lingkungan sosial sehingga menggangap dirinya adalah real creator. Berlandaskan pada akal sebagai dewa penyelamat bagi dirinya menjadikan dirinya termasuk dalam kategori orang yang mengalami gangguan kesehatan mental (neurose dan pcychose).

Ajaran sufistik dalam memberikan solusi adalah dengan konsep takhalli, tahalli dan tajalli menjadi aspirin bagi jiwa manusia. Melalui dzikir dan wirid yang diberikan oleh seorang mursyid arif billah sehingga dzikir tersebut dapat memberi manfaat dan dapat menerangi batinnya, dari qolb yang ghoflah (kondisi hati yang lalai, yaitu tidak mengingat Alloh), intibah (hati yang telah bangun dari tidurnya atau lalai), yahdoh (hati yang sadar), hudur (hati yang hadir, yaitu hadirnya hati ketika berdzikir), muroqobah (mengawasi, memperhatikan gerak gerik hati, yaitu hati yang sudah mampu memperhatikan siapa yang memperhatikannya), musyahadah(menyaksikan), muwajahah (bertemu), iman taqlid, iman ilmu, iman iyan, iman haq, iman hakekat dan pada puncaknya menjadi manusia sempurna atau insan kamil. Sehingga manusia dapat mengenal hakikat diri seorang hamba yang harus rela dan cinta pada ketentuan dari yang Maha Kuasa.
\end{abstract}

Kata Kunci: Manusia, Zikir, Wirid, Mursyid 


\section{A. Pendahuluan}

Setiap manusia di dalam kehidupan sehari-harinya tentu pernah mengalami kegagalan atau ketidaksesuaian kenyataan yang dihadapi dengan harapan sebelumnya. Kondisi ini dapat mengarahkan dia ke situasi yang tidak nyaman, yang membuat dirinya sedih, cemas, ragu-ragu, atau bingung. Kondisi ini adalah salah satu ciri adanya gangguan psikis, yang mana di bidang psikologi di antaranya dikenal sebagai kondisi stres.

Stres di dalam istilah bahasa asing dikenal dengan stress, diartikan oleh seorang psikolog perkembangan JW Santrock sebagai respon individu terhadap situasi dan peristiwa yang dianggap mengancam. Ahli lain, Magill juga menyatakan bahwa stres merupakan reaksi adaptif individu terhadap situasi yang dipersepsikan sebagai ancaman. Situasi mengancam ini menjadi situasi yang sulit diatasi oleh individu yang bersangkutan. Seringkali membutuhkan waktu lama dan bahkan tidak jarang gagal mengatasinya, sehingga pada tahap berikutnya ia mengalami kesulitan dalam bekerja ataupun melakukan aktivitas keseharian lainnya. Islam mengenalkan stres di dalam kehidupan ini sebagai cobaan. Allah SWT berfirman di dalam Al Qur'an surat Al Baqarah (2) ayat 155 yang artinya "dan sungguh akan Kami berikan cobaan kepadamu, dengan sedikit ketakutan, kelaparan, kekurangan harta, jiwa dan buah-buahan. dan berikanlah berita gembira kepada orangorang yang sabar".

Datangnya cobaan kepada diri kita inilah yang akan dirasakan sebagai suatu stres (tekanan) dalam diri, atau disebut juga sebagai beban. Banyak contoh dalam keseharian kita bentuk-bentuk cobaan ini, misalnya kematian, sakit, dan kehilangan. Bukan hanya kondisi yang buruk menjadi cobaan, namun kekayaan, anak, kepandaian dan jabatan juga menjadi cobaan bagi manusia.

Surat al Baqarah ayat 10 menyatakan kondisi stres dan gangguan psikologis yang mengikuti manusia sebagai penyakit hati. Lebih jelasnya berbunyi "dalam hati mereka ada penyakit, lalu ditambah Allah penyakitnya dan bagi mereka siksa yang pedih, disebabkan mereka berdusta."

Penyakit hati ini diartikan sebagai sifat kedengkian, iri-hati dan dendam terhadap orang lain. Sifat dan perasaan ini menjadikan seseorang senantiasa merasa terancam oleh sesuatu yang sesungguhnya dapat dihindari. Situasi atau peristiwa yang memunculkan stres disebut sebagai stressor atau sumber stres. Segala sesuatu yang ada di lingkungan manusia dapat menjadi stressor, baik berupa lingkungan keluarga, masyarakat, sekolah, tempat kerja, dan tempat umum. Orang lain yang ada di sekitar kita juga dapat menjadi stressor, sebagaimana benda fisik seperti ruangan, angkutan umum, kemacetan, cuaca, dan sebagainya.

Berdasarkan latar belakang tersebut, bagaimanakah peran tasawuf dalam mengelola stress? 


\section{B. Makna Qolbu}

Secara bahasa asal kata "Qalb" bermakna membalikkan memalingkan atau menjadikan yang di atas ke bawah ke luar. Qalbu dalm bentuk masdar atau kata benda mengandung arti lubuk hati, akal, kekuatan, semangat dan keberanian.

Pengertian Qalb disini arti rohaniyah dan ia tidak dapat dilihat dengan mata kepala kecuali dengan penglihatan batiniyah (mukasyafah). Ia merupakan tempat menerima perasaan kasih sayang, pengajaran, pengetahuan, berita, kekuatan, keimanan, keIslaman, keihsanan, dan ketauhidan.

Salah satu istilah penting yang banyak dibicarakan dalam kitab tasawuf adalah qalb (hati). Dalam arti fisik, hati adalah segumpal daging (jantung) yang terletak di sebelah kiri dada, sedangkan arti spiritual hati adalah pusat kearifan dan pemahaman. Dalam dunia tasawuf, hati dipandang sebagai sumber kebaikan serta kejahatan, sumber pemahaman tentang keagamaan, dan tempat hadirnya sang Ilahi. Menurut para ulama, hati merupakan sumber pengetahuan tentang Tuhan, alam semesta dan manusia. Dalam Al Quran hati disebut sebanyak 132 kali (menunjukkan betapa pentingnya dan luasnya makna hati) dengan makna dasar "berbalik", "maju mundur", "berubah", dan "naik turun". Sesuai dengan makna dasarnya, istilah hati dalam $\mathrm{Al}$ Quran merujuk pada tempat kebaikan serta kejahatan, kebenaran serta kesalahan, dan keimanan serta kekufuran. ${ }^{1}$

Para ahli medis telah membicarakan hati (qalbu/jantung). Anggota tubuh ini menampung darah dari pembuluh darah dan menyebarkannya melalui dua saluran paru-paru (pulmonary artery) menuju paru-paru untuk membersihkan darah tersebut. Kemudian ia menampungnya lagi dari dua saluran tersebut setelah membersihkannya, lalu menyebarluaskannya dari dua saluran pembuluh darah utama (arteritis) ke seluruh tubuh. ${ }^{2}$

Sebagian ulama mengatakan bahwasanya qalbu adalah jantungnya ruh, sebagaimana jantung yang berdenyut adalah simbol kehidupan dan kematian. Karenanya, sesungguhnya hati di dalam ruh merupakan simbol keimanan dan kekufuran, atau sesuatu yang mengembangkan perasaanperasaan manusia, kepekaan-kepekaannya, dan kebimbangannya: rasa cinta, marah, kecenderungan menyukai dan dengki, spiritualisme dan kesombongan, kekuatan dan kelemahan, keimanan dan kekufuran, ketenangan dan kekhawatiran, keyakinan dan keraguan, kerelaan dan ketidakpuasan, cahaya dan kegelapan. ${ }^{3}$

\footnotetext{
${ }^{1}$ Nurcholis Madjid, Ensiklopedi Islam Untuk Pelajar, jld. 2 (Jakarta: PT Ichtiar Baru van Hoeve, 1998), h. 94

2 Said Abdul Azhim, Rahasia Kesucian Hati, ter. Ade Hidayat (Jakarta: Qultum Media, 2006), 1 Qultum Media, 2006),h. 1

${ }^{3}$ Ibid, 2-3
} 
Kalbu (Al-Qalb) merupakan salah satu daya Nafsani. Para ahli berbeda pendapat dalam menentukan maknanya. Sebagian ada yang mengasumsikan sebagai materi organik (Al-Adhum Al-Madi) sedangkan sebagian yang lain menyebut sebagai sistem kognisi (Jihaz ma'rifi) yang berdaya emosi (Al-Syu'ur). Dalam psikologi kontenporer, kata kalbu kata kalbu umumnya digunakan untuk makna al-Syu'ur (emosi) yaitu perasaan yang diketahui.dan di dasari. Penting untuk dicatat bahwa qalbu adalah komponen sentral manusia. Sedemikian pentingnya dan sentralnya peranan kalbu bagi manusia, ia di anggap sebagai penentu baik buruk manusia. AlQur'an termasuk rahasia manusia,yang merupakan anugrah Allah SWT yang paling mulia. Hal ini karena dengan qalb ini, manusia mampu beraktifitas sesuai dengan hal-hal yang diperintahkan oleh Allah. Qolb berperan sebagai sentral kebaikan dan kejahatan manusia, walaupun pada hakikatnya cendrung pada kebaikan. ${ }^{4}$

Menurut Rizal Ibrahim, qalb (hati) mengandung pengertian yang terbagi dalam dua bentuk:

1. Jantung yang berupa segumpal daging berbentuk bulat memanjang, yang terletak di pinggir dada sebelah kiri, yaitu segumpal daging yang mempunyai tugas khusus yang di dalamnya ada rongga-rongga yang mengandung darah hitam sebagai sumber ruh. Adalah tak perlu menjelaskan tentang bentuk dan cara kerjanya, karena hal itu menyangkut bidang kedokteran dan tidak ada hubungannya dengan agama. Hati serupa juga ada pada hewan, bahkan ada pula pada orang yang telah mati. Maka bila disebut al-qalb, sesungguhnya bukanlah termasuk alam nyata, seperti alam yang dapat ditangkap oleh panca indera kita.

2. Hati berupa sesuatu yang halus (latifah) bersifat ketuhanan (rabbaniyyah) dan ruhani yang ada hubungannya dengan hati jasmani. Hati yang halus itulah, hakikat manusia yang dapat menangkap segala rasa dan dapat mengetahui dan mengenal segala sesuatu. Hati atau yang disebut al-qalb inilah yang kita tuju sebagai hakikat manusia, yang akan disiksa, dicerca, dan dituntut dan dia pula pemikul amanat Allah SWT. Ia mempunyai hubungan dengan hati jasmani. Karena eratnya hubungan antara hati jasmani dengan hati nurani itu, hingga kebanyakan akal manusia tak sanggup mengetahuinya dalam hal posisi hubungannya. ${ }^{5}$

Hubungan kedua hati itu seperti halnya sifat dengan jisim yang disifati, atau benda yang dijadikan perkakas dengan perkakasnya, atau seperti benda yang telah berurat berakar dengan tempatnya. Hati adalah tempat bergantungnya kemunafikan sebagaimana bergantungnya keimanan. Hati adalah rahasia dari rahasia-rahasia yang tidak diketahui hakikatnya yang

\footnotetext{
${ }^{4}$ Abd Aziz, Filsafat Pendidikan Islam..., hal 36

${ }^{5}$ Rizal Ibrahim, Menghadirkan Hati (Yogyakarta: Pustaka Sufi, 2003), h. 87
} 
tersembunyi di dalamnya, kecuali oleh Allah SWT. Karenanya, akidah manusia dan segala yang dikerjakannya, yang baik ataupun yang buruk, semuanya merujuk pada segumpal daging (mudghah) yang ada di dalam tubuh. $^{6}$

Pendapat lain mengatakan hati adalah Raja Pengatur stabilitas (The Central Emotion) bagi seluruh anggota tubuh manusia bukanlah semata hati jasmani berupa segumpal daging, yang berbentuk bulat memanjang, berisikan rongga-rongga, dan mengandung darah hitam, melainkan juga sesuatu yang abstrak. Ia termasuk ihwal ruhaniyah yang sulit ditembus oleh kekuatan inderawi. Ia tidak seperti hati pada fisik binatang dan manusia tatkala sudah tak bernyawa. Dia adalah: "Jisim yang sangat halus, terletak di dalam hati yang berupa daging, seperti menempelnya sifat pada benda yang disifatinya". ${ }^{7}$

"Ketahuilah, bahwa di dalam tubuh terdapat segumpal darah. Apabila kondisinya baik, akan baik pula seluruh tubuh. Apabila kondisinya memburuk, akan buruk pula seluruh tubuh. Ketahuilah, segumpal darah itu adalah hati". ${ }^{8}$

Artinya bahwa hati adalah raja bagi organ tubuh manusia, dan organ tubuh manusia adalah pelaksana apa saja yang diinginkan hati, penerima petunjukknya, dan semua aktifitas organ tubuh tidak ada artinya tanpa adanya niat dari hati. Semua organ tubuh berada di bawah perbudakan hati, dan di bawah kendalinya. Dari hati pula konsekwen (istiqomah) di atas jalan yang benar, dan penyimpangan itu berasal. Hati kelak dimintai pertanggungan jawab tentang kepemimpinannya terhadap organ tubuh. Karena setiap pemimpin akan dimintai pertanggungan jawab tentang kepemimpinannya terhadap rakyatnya, maka konsentrasi perbaikan dan pelurusan hati harus menjadi fokus para salikin (pejalan spiritual), dan deteksi penyakit-penyakit hati sekaligus upaya penyembuhannya harus diperhatikan dengan serius oleh para ahli ibadah dalam ibadahnya kepada Allah SWT.

Hati memiliki aspek atau fungsi lain yang lebih penting dari yang disebutkan di atas. Hati memiliki tempat bergantung dan di dalam hati dan sifat manusia terkandung permohonan pertolongan, yang dengannya Allah menunjukkan Diri-Nya kepada manusia sebagai Yang Maha Menolong dan Memelihara. Tubuh manusia adalah dimensi fisik dan eksistensinya, sedangkan hati merupakan dimensi spiritualnya. Karena alasan ini hati adalah lidah pengetahuan Allah yang langsung fasih, paling jelas, agung dan benar. Dan karenanya hati lebih diterima sebagai satu-satunya eksponen dari

${ }^{6}$ Ibnu Katsir, Tafsir Al-Qur'an Al-'Adzim, ter. Bahrun Abu Bakar, juz 21 (Bandung: SinarBaru Algesindo, 2004), h. 159

${ }^{7}$ Uwes al-Qorni, 60 penyakit hati, (Bandung: Remaja Rosdakarya, 1999), h. V

${ }^{8}$ Muslim bin Al-Hajjaj, Shahih Muslim, Juz 8 (Beirut: Dar Al-Kutub, 1995), h. 290 
kebenaran luhur oleh seluruh makhluk, sebagai gerbang mengenal Allah. ${ }^{9}$ Ibnu Qayyim mengatakan bahwa hati itu mempunyai dua ciri; hidup atau mati. Atas dasar itulah hati terbagi ke dalam tiga jenis; hati yang sehat (Qolbun salim); hati yang mati; dan hati yang sakit. ${ }^{10}$

Merujuk pada makna qolb di atas, maka stressor yang paling mempengaruhi diri manusia adalah stressor internal yaitu kondisi hati yang berubah-ubah, oleh karen itu diperlukan penstabil internal.

\section{Ajaran Tasawuf dan Garis Besarnya}

Ajaran tasawuf adalah proses peleburan dan penggabungan jala-jala sistem berpikir menjadi sebuah kerangka keyakinan oleh sebagian umat Islam hingga terwujud suatu sentrum sebagian identitas wujudiyah (eksitas) kemanusiaan yang berorientasi kepada ketuhanan. ${ }^{11}$ Sufistik yang terbangun dari kata sufi merupakan seseorang yang telah membersihkan jiwanya dari sifat-sifat tercela dengan mengingat Allah. Meyakini-Nya sebagai sumber hidup dan kehidupan, tempat meminta yang bersifat Pengasih dan Maha Pengatur dari hakekat segala-galanya, sehingga terhindar dari perbuatan amoral dan mencapai pengetahuan hakiki (ma'rifat). Seorang yang bertitel sufi berusaha mengaplikasikan sifat-sifat baik Tuhannya menjadi sifatnya.

Kumulatif dari seluruh ajaran tasawuf dapat diajarkan dan dididikkan oleh sufi termasuk pada kegiatan pembinaan kesehatan mental. Hal ini disebabkan tasawuf adalah bagian dari ajaran agama Islam yang telah diyakini eksistensinya. Seorang sufi memiliki kemampuan mengontrol nafsu, emosi dan mendidikkannya kepada orang lain khsusunya dalam pembinaan kesehatan mental. Firman Allah SWT dalam surah ar-Rad ayat 28.

Artinya: (yaitu) orang-orang yang beriman dan hati mereka manjadi tenteram dengan mengingat Allah. Ingatlah, Hanya dengan mengingati Allah-lah hati menjadi tenteram.

Demikian juga dalam surah Fusilat ayat 30:

Artinya:

Sesungguhnya orang-orang yang mengatakan: "Tuhan kami ialah Allah" Kemudian mereka meneguhkan pendirian mereka, Maka malaikat akan turun kepada mereka dengan mengatakan: "Janganlah kamu takut dan janganlah merasa sedih; dan gembirakanlah mereka dengan jannah yang Telah dijanjikan Allah kepadamu".

Dari penjelasan tersebut dipahami bahwa ada korelasi antara zikir kepada Tuhan dengan kedamaian hati. Korelasi antara istiqamah bertuhan

\footnotetext{
${ }^{9}$ Fathullah Gulen, Kunci-Kunci Rahasia Sufi, (Jakarta: Raja Grafindo, 2001), h. 56

${ }^{10}$ Ibnu Qayyim al-Jauziyyah, Keajaiban Hati, ter. Fadhli Bahri (Jakarta:Pustaka Azzam,2002), h. 17

${ }^{11}$ A. Rivai Siregar, Tasawuf dari Sufisme Klasik ke Neosufisme, (Jakarta: Raja Grafindo Persada, 2000), h. 12.
} 
dengan janji ketenangan dan kedamaian dapat juga dirasakan ketika kita mengikuti ritual ibadah secara bersama-sama, maka lebih dari lima puluh persen beban pikiran seperti resah, stress serta gelisah dapat terlupakan dan terasa sejuk dengan siraman rohani berikutnya. Dengan demikian jelaslah bahwa zikir kepada Allah itu merupakan salah-satu ajaran dari sufisme Islam yakni tasawuf, dapat dijadikan terapi pengobatan meraih kesehatan mental.

Seorang sufi amat mementingkan zikir kepada Allah yang berpusat dalam al-Qalb. Di dalam qalb terdapat fuad yaitu hati nurani yang kesadarannya lebih mendalam, lebih tajam dari pada qalb. Pusat gravitasi nafsiah pun terletak di dalam qalb dimana gravitasi nafsiah mengendalikan seluruh kemampuan nafsiahnya, baik potensi aktualita. Baik buruknya kedua kemampuan itu bergantung pada kualitas gravitasi nafsiah. Itulah sebabnya al-Quran menjadikan qalb sebagai titik sentral pembinaan. ${ }^{12}$ Hal ini dinyatakan Allah dalam firman-Nya surah al-Isra ayat 82

Artinya:Dan kami turunkan dari Al Quran suatu yang menjadi penawar dan rahmat bagi orang-orang yang beriman dan Al Quran itu tidaklah menambah kepada orang-orang yang zalim selain kerugian.

Ayat di atas dipahami bahwa Allah menyatakan al-Quran sebagai obat bagi siapa yang percaya. Seorang sufi membiasakan dan membudayakan zikir kepada Allah melalui sinyal qalb nafsiah khususnya dalam pendekatan dirinya kepada Allah. Untuk mencapai tujuan pendekatan diri kepada-Nya, tasawuf menawarkan langkah-langkah dan ajarannya sebagai berikut:

Konsep Dasar Ajaran Tasawuf

\begin{tabular}{|l|l|l|l|}
\hline No & Tahapan & $\begin{array}{l}\text { Aspek dan } \\
\text { Mediator }\end{array}$ & PenerapanTasawuf \\
\hline
\end{tabular}

${ }^{12}$ Sukanto dan A. Dardiri Hasyim, Nafsiologi; Refleksi Analisis Tentang Diri dan Tingkah Laku Manusia, (Surabaya: Risalah Gusti, 1995), h. 81. 


\begin{tabular}{|c|c|c|c|}
\hline \multirow[t]{2}{*}{1.} & \multirow[t]{2}{*}{$\begin{array}{l}\text { Takhalli: } \\
\text { Mengosongkan } \\
\text { diri dari sifat-sifat } \\
\text { tercela }\end{array}$} & $\begin{array}{l}\text { Jasmani: } \quad \text { mata, } \\
\text { mulut, } \quad \text { hidung, } \\
\text { telinga, } \quad \text { perut, } \\
\text { kelamin, tangan, } \\
\text { dan kaki }\end{array}$ & $\begin{array}{l}\text { Memelihara anggota tubuh di } \\
\text { atas dari hal-hal yang bersifat } \\
\text { maksiat, kemungkaran, zalim, } \\
\text { ucapan kotor dan sebagainya. }\end{array}$ \\
\hline & & $\begin{array}{l}\text { Rohani: Qalbu, } \\
\text { hati, dan nurani }\end{array}$ & $\begin{array}{l}\text { Memelihara qalbu dari sifat } \\
\text { angkuh, sombong, egois, } \\
\text { dendam, adu domba, memecah } \\
\text { persatuan dan kesatuan, cemburu } \\
\text { buta, dan sebagainya. }\end{array}$ \\
\hline \multirow[t]{2}{*}{2.} & \multirow{2}{*}{$\begin{array}{l}\text { Tahalli: Mengisi } \\
\text { yang manis, terpuji } \\
\text { yaitu ketaatan lahir } \\
\text { dan batin }\end{array}$} & $\begin{array}{l}\text { Lahiriyah: } \\
\text { dan akhlak }\end{array}$ & $\begin{array}{l}\text { Memperbanyak ibadah, zikir, } \\
\text { dan amal perbuatan terpuji dan } \\
\text { saleh }\end{array}$ \\
\hline & & $\begin{array}{l}\text { Bathiniah: } \quad \text { maqam- } \\
\text { maqam para sufistik }\end{array}$ & $\begin{array}{l}\text { Menjaga qalbu dari iri hati yang } \\
\text { membuat orang menderita, } \\
\text { minder, cemburu dan lain } \\
\text { sebagainya }\end{array}$ \\
\hline 3. & $\begin{array}{lr}\text { Tajalli: } & \\
\text { Pengalaman } & \\
\text { spiritual } & \text { yang } \\
\text { merasakan } & \text { jelas } \\
\text { kehadiran } & \text { Tuhan } \\
\text { dalam } & \\
\text { kehidupannya } & \end{array}$ & $\begin{array}{lr}\text { Aspek bathiniah } \\
\text { yakni perasaan } \\
\text { kedamaian qalbu } \\
\text { dan pemantapan } \\
\text { ihsan } & \text { dalam } \\
\text { kehidupan } & \text { sehari- } \\
\text { hari } & \end{array}$ & $\begin{array}{l}\text { Pencapaian ma'rifatullah yaitu } \\
\text { perasaan keinsanan lenyap, rasa } \\
\text { ke-Tuhanan dalam keadaan sama } \\
\text { semua rahasia yang membatasi } \\
\text { diri dengan Allah tersingkap } \\
\text { kasyaf, ketika itu antara diri } \\
\text { dengan Allah menjadi satu dalam } \\
\text { baqa-Nya sehingga Allah terasa } \\
\text { hadir setiap saat dimana dan } \\
\text { kapan saja. }\end{array}$ \\
\hline
\end{tabular}

Ajaran-ajaran tasawuf banyak ditemukan pada tahapan tahalli seperti adanya maqamat sebagai tempat transit. Melatih diri dengan berbagai sifat terpuji dalam praktek hidup langsung. at-Tusi menjelaskan bahwa tempattempat transit menuju keridhaan kepada Allah antara lain adalah taubat, wara', zuhud, fakir, sabar, tawakkal dan ridha. Demikian juga Iman Ghazali melihat stasiun tempat transit seorang hamba dalam pendekatan diri kepada Allah adalah taubat, sabar, fakir, zuhud, tawakkal, cinta dan kerelaan. ${ }^{13}$ Sifatsifat tersebut di atas mestilah dimiliki dan dipraktekkan sabagai amalan seseorang yang tengah mengamalkan ajaran tasawuf. Dengan mengikuti maqam dalam ajaran tasawuf secara berangsur-angsur akan menambah kesadaran dan kema'rifatan kepada Allah sehingga ia sendiri mengenal jati

${ }^{13}$ Harun Nasution, Filsafat dan Mistisme dalam Islam, (Jakarta: Bulan Bintang, 1989), h. 62 
dirinya sebagai makhluk Tuhan yang tidak lepas dari dinamika hidup.

\section{Peran Tasawuf dalam mengelola Stress}

Sifat dasar qolb yang bolak balik dan tidak stabil, sebagaimana yang telah dipaparkan di atas, maka kondisi tersebut menjadi sumber stres internal manusia, sehingga qolbu memerlukan penstabil. Adapun yang dapat menenangkan dan menentramkan Qolb yaitu dzikir, wirid dan riyadoh.

a. Dzikir

Dzikir ditinjau dari segi bahasa (lughatan) adalah mengingat, sedangkan dzikir secara istilah adalah membasahi lidah dengan ucapanucapan pujian kepada Allah. ${ }^{14}$

Secara etimologi dzikir berasal dari kata "dzakara" berarti menyebut, mensucikan, menggabungkan, menjaga, mengerti, mempelajari, memberi dan nasehat. Oleh karena itu dzikir berarti mensucikan dan mengagungkan, juga dapat diartikan menyebut dan mengucapkan nama Allah atau menjaga dalam ingatan (mengingat). ${ }^{15}$

Dzikir merupakan ibadah hati dan lisan yang tidak mengenal batasan waktu. Bahkan Allah menyifati ulil albab, adalah mereka-mereka yang senantiasa menyebut Rabnya, baik dalam keadaan berdiri, duduk bahkan juga berbaring. Oleh karenanya dzikir bukan hanya ibadah yang bersifat lisaniyah, namun juga qalbiyah. Imam Nawawi menyatakan bahwa yang afdhal adalah dilakukan bersamaan di lisan dan di hati. jika harus salah satunya, maka dzikir hatilah yang lebih di utama. Meskipun demikian, menghadirkan maknanya dalam hati, memahami maksudnya merupakan suatu hal yang harus diupayakan dalam dzikir. ${ }^{16}$

Pada hakikatnya, orang yang sedang berdzikir adalah orang yang sedang berhubungan dengan Allah. Seseorang yang senantiasa mengajak orang lain untuk kembali kepada Allah akan memerlukan dan melakukan dzikir yang lebih dari seorang muslim biasa. Karena pada dasarnya, ia ingin menghidupkan kembali hati mereka yang mati, akan tetapi jika ia tidak menghidupkan hatinya lebih dulu, keinginan atau kehendaknya untuk menghidupkan hati yang lain tidak akan mampu dilakukan.

Firman Allah SWT dalam surah ar-Rad ayat 28.

Artinya: (yaitu) orang-orang yang beriman dan hati mereka manjadi tenteram dengan mengingat Allah. Ingatlah, Hanya dengan mengingati Allah-lah hati menjadi tenteram.

${ }^{14}$ Ismail Nawawi, Risalah Pembersih Jiwa: Terapi Prilaku Lahir \& Batin Dalam Perspektif Tasawuf (Surabaya: Karya Agung Surabaya, 2008), h. 244.

${ }^{15}$ Hazri Adlany, et al, al-Qur'an Terjemah Indonesia (Jakarta: Sari Agung,2002), h. 470.

${ }^{16}$ Nawawi, Risalah Pembersih Jiwa, h. 244 
Dzikir adalah melepaskan diri dari kelalaian dengan selalu menghadirkan qolbu bersama al-Haqq (Allah). Pendapat lain mengatakan bahwa dzikir adalah mengulang-ulang nama Allah dalam hati maupun melalui lisan. Hal tersebut bisa dilakukan dengan mengingat lafal jalalah (Allah), sifat-Nya, hukum-Nya, perbuatan-Nya atau suatu tindakan yang serupa. Dzikir bisa pula berupa doa, mengingat para rasul-Nya, nabiNya,wali-Nya, dan orang-orang yang memiliki kedekatan dengan-Nya, serta bisa pula berupa takarub kepada-Nya melalui sarana dan perbuatan tertentu seperti membaca, mengingat, bersyair, menyanyi, ceramah, dan bercerita.

Maka, dengan pemahaman seperti ini, mereka yang berbicara tentang kebenaran Allah, atau yang merenungkan keagungan, kemuliaan, dan tandatanda kekuasaan-Nya di langit dan di bumi, atau yang mengerjakan perintahNya dan menjauhi larangan-Nya sesungguhnya dengan berbuat demikian mereka sedang melakukan dzikir. Dzikir bisa dilakukan dengan lisan, qalbu, anggota badan, ataupun dengan ucapan yang terdengar orang. Orang yang berdzikir dengan menggabungkan semua unsur tersebut berarti telah melakukan dzikir secara sempurna.

Tahap pertama adalah dzikir lisan. Kemudian dzikir qalbu yang cenderung diupayakan dan dipaksakan. Selanjutnya, dzikir kalbu yang berlangsung secara lugas, tanpa perlu dipaksakan. Serta yang terakhir adalah ketika Allah sudah berkuasa di dalam kalbu serta sirnanya dzikir itu sendiri. Inilah rahasia dari sabda Nabi saw., "Siapa ingin bersenang-senang di taman surga, perbanyaklah mengingat Allah." Juga sabda Nabi saw., "Dzikir diam (khafiy) tujuh puluh kali lebih utama daripada dzikir yang terdengar oleh para malaikat pencatat amal."

Sebagai tanda bahwa sebuah dzikir sampai pada sirr (nurani terdalam pada jiwa yang kelak menjadi tempat cahaya penyaksian) adalah saat pedzikir dan objek dzikirnya lenyap tersembunyi. Dzikir sirr terwujud ketika seseorang telah terliputi dan tenggelam di dalamnya. Tandanya, apabila engkau meninggalkan dzikir tersebut, ia takkan meninggalkanmu.

Sebagai kesimpulan tentang tahapan dzikir, Ibnu Atha'illah mengatakan, berdzikir dengan ungkapan kata-kata tanpa rasa hudhur disebut dzikir lisan, berdzikir dengan merasakan kehadiran qolbu bersama Allah disebut dzikir qalbu, sementara berdzikir tanpa menyadari kehadiran segala sesuatu selain Allah disebut dzikir sirr. Itulah yang disebut dengan dzikir khafiy.

\section{b. Wirid}

Para pengamal wirid bertingkat-tingkat. Ahli wirid pemula memang masih banyak yang berorientasi 'amalan oriented', sebagaimana disebutkan tadi. Namun, ahli wirid bisa meningkat ke jenjang lebih tinggi ketika mulai merasakan suasana batin melalui penghayatan terhadap makna dan tujuan 
wirid. Jika ahli wirid sudah sampai di maqam terbaik, Ibnu 'Athaillah memesankan: "Jangan kita menganggap rendah hamba yang mengamalkan wirid dan ibadah tertentu karena keduanya memiliki keduduk-an yang mulia di sisi Allah." 17

Ia menambahkan: "Jika engkau melihat seorang hamba yang ditetapkan Allah selalu menjaga wiridnya, tetapi lama ia tidak mendapatkan pertolongan dan kekhususan dari-Nya, jangan sampai engkau meremehkannya, hanya karena engkau belum melihat tanda-tanda orang 'arif atau cahaya indah seorang pencinta Allah pada diri hamba itu. Kalaulah bukan karunia berupa warid, tentu tidak akan ada wirid."18 Orang yang konsisten mengamalkan wirid dan sudah sampai ke tingkat penghayatan lebih mendalam terhadap wiridnya, wirid itu berangsur-angsur -melahirkan warid.

Warid ialah efek positif yang lahir dari pengamalan wirid secara istikamah. Ibnu '-Athaillah menyebut warid itu sebagai pemberian dan hidayah Allah SWT berupa petunjuk, cahaya ilahi, dan kesenangan batin di -dalam ber-taqarrub kepada-Nya. ${ }^{19}$

Ibnu 'Athaillah mengatakan: "Allah memberimu warid untuk menyelamatkanmu dari cengke-raman dunia dan membebaskanmu daripada diperbudak oleh makhluk apa pun." ${ }^{20}$ Ia membagi warid ke dalam tiga tingkatan, yaitu 1) warid yang muncul pada ahli wirid berupa hamba merasa ringan dalam menjalankan ketaatan dan beribadah karena sudah merasa lebih dekat ke hadirat-Nya. 2) Warid yang muncul pada ahli wirid brupa hamba sudah merasakan puncak keikhlasan dan sudah mampu melepaskan diri dari tujuan apa pun selain hanya kepada Allah SWT. 3) Warid yang muncul pada ahli wirid berupa kekuatan untuk melepaskan diri dari sifat-sifat wujud yang terbatas (sempit) untuk kemudian menyaksikan kebesaran Allah Ta'ala yang tidak terbatas.

Menurut Ibnu 'Athaillah, wirid paling tinggi ialah: "Allah memberimu warid untuk melepaskanmu dari penjara wujudmu ke alam syuhud (penyaksian)." Warid ini sudah sampai ke tingkat pe-nyingkapan (maqam syuhud atau -mukasyafah). Jika seseorang sudah sampai di maqam ini, ia meraih ketenangan batin dan sudah terbebas dari teriakan atau bisikan dunia. Kalaupun sempat, ia akan segera kembali.

Orang-orang yang sudah memperoleh warid dengan sendirinya orang itu memilki kepribadian zuhud, dalam arti tidak lagi akan didikte oleh

17

Nasaruddin

Umar,

Wirid

dan

Warid,

http://mediaindonesia.com/read/detail/109598-dari-wirid-ke-warid, di akses tanggal 14 Agustus 201817.00 pm.

${ }^{18}$ Ibid.

${ }^{19}$ Ibid.

${ }^{20}$ Ibnu Athoilah, Syarah Al-Hikam, Haramain, h. 30 
kepentingan dunia. Dia sudah diberi kemampuan untuk memilki dirinya sendiri tanpa tergantung kepada kekuat-an makhluk.

Baginya, cukup dengan kasih-sayang Allah SWT. Warid sudah menjadi semacam cahaya Tuhan (nur Allah) yang memantul mengendalikan diri dalam batin dan pikirannya sehingga kekuatan itu menjadi perisai terhadap berbagai kemungkaran.

Kalaupun mereka tergelincir, secepatnya ia akan mengendalikan diri, kembali ke jalan yang -benar atau yang lebih benar. Warid tidak perlu dicari, tetapi akan datang dengan sendiri-nya ketika amalan dan komitmen wirid dan zikir hamba-Nya betul-betul dijalankan secara konsisten.

c. Riyadoh

Kata Riyadhoh terambil dari kata Ar-Riyadhu, Ar-Raudhu semakna dengan At-Tamrin yang mengandung arti: latihan atau melatih diri. Dalam riyadhoh, kita berlatih untuk membiasakan diri melaksanakan ibadah-ibadah mahdhoh (ritual) dan ghairu mahdhoh. Sehingga, kedua macam ibadah itu menjadi budaya hidup kita sehari-hari. ${ }^{21}$

Riyadhoh, atau disiplin asketis atau latihan kejuhudan dipahami oleh ibnu Arabiy sebagai: tahdzibul akhlak (pembinaan ahklak) yaitu tankiyyatuha watathiiruha mimma laa yaliiku biha (penyucian dan pembersihan jiwa dari segala hal yang tidak patut untuk jiwa). Karena itu riyadhoh adalah alat dan bukan tujuan.

Disamping istilah Riyadhah, para ulama Tasawwuf juga menggunakan istilah 'mujahadah'. Imam Al-Qusyairi menempatkanya dalam rangkaian maqomat atau madarij arba as-saluk, sedangkan Abdul Wahab Sa'roni menempatkanya sebagai bagian dari Adab al-murid Finafsihi (etika murid terhadap diri sendiri).

Para ulama thoriqoh melandaskan riyadhoh ataw mujahadah ini pada banyak ayat Alqur'an hadist Rosululloh dan penuturan pengalaman para ulama tashowuf. Di antara ayat Al-qur'an yg mereka jadikan pegangan antara lain: firman Alloh : wa amma man khofa maqoma robbihi wa nahannafsa a'nil hawa faa innal jannata hiyal ma'wa (ma'wa tempt tinggal) (QS An najiat: 40-41).

Demikian pula ayat lain: walladziini jaahaduu fiina lanahdiyannahum subulana wa innalloha lama'al muhsiniin (Qs $\mathrm{Al}$ ankabut 69) Adapun hadist yang di jadikan landasan adalah penegasan Rosululloh yaitu tentang fungsi kerosulanya; inama buistu li utammima makarimal akhlak (HR Baehaki dari Abu Hurairoh).Atau Hadist lain; afdolull jihad

\footnotetext{
${ }^{21}$ Achmad Syarif Hidayat, Riyadhoh dan Mujahadah, https:dokumenpemudatqn.blogspot.com/2012/06/mengenal-riyadohriyadhah-dalamtarekat.html, 06 April 2012
} 
kalimatu adlin inda shultonin jaiirin; Jihad yg paling utama adalah mengemukakan kata keadilan dihadapan penguasa yg semena mena (HR Abu daud) Mengemukakan keberanian d hadapan penguasa dolim tentu membutuhkan keberanian dan tidak takut kecuali dgn Alloh . sifat ini tidak mungkin menjelma bila kita masih dikuasai hawa nafsu dan cinta dunia.

Urgensi riyadhoh atau mujahadah dikemumakan oleh banyak ulama, Abu Ali ada-daqok guru imam Qusyairi, menyatakan: Man jayyana dhohirohu bil mujahadah (riyadoh) hassanallohu sarooirohu bil msyahadah, wa'lam anna man lam yakun fi bidayatihi shohiba mujahadatin lam yajid min hadihit thoriqotihi (siapa yang menghiasi lahiriyahnya dgn mujahadah (riyadoh) Alloh memperindah bathinnya dgn kemampuan musyahadah (menyaksikan ke agungan Alloh dgn hatinya, menyaksikan yang ghoib sejelas yg di lihat mata lahiriyahnya) Dan ketahuilah bahwa siapa yang pada awalnnya tdk mujahadah, maka ia tdk akan mencicipi semerbak aroma wangi dalam Thoriqoh.

Dzikir dan wirid tidak aka memberikan manfaat dan tidak dapat menerangi batin jika tidak mendapat bimbingan langsung dari seoarng syeh atau mursyid yang arif billah. ${ }^{22}$ Disinlah pentingnya seorang mursyid yang arif billah sehingga mampu membimbing murid sampai kepada tujuan yang hakiki, yaitu Alloh SWT. Ketika seorang murid mengikuti murobi mursyidnya dengan taat maka murid tidak akan merasakan takut dan sedih. Sebagaimana dalam Al-qur'an surat al baqoroh ayat 38:

Artinya: Maka barang siapa yang mengikuti petunjuk-Ku, niscaya tidak ada kekhawatiran atas mereka, dan tidak (pula) mereka bersedih hati".

Ali Imron ayat 31:

Artinya:Katakanlah: "Jika kamu (benar-benar) mencintai Allah, ikutilah aku, niscaya Allah mengasihi dan mengampuni dosa-dosamu." Allah Maha Pengampun lagi Maha Penyayang.

Dari ayat di atas menunjukan pentingnya seorang guru dalam membina ruhani. Tujuan melakukan dzikir, wirid dan riyadoh yaitu untuk menenangkan, menggembirakan dan menentramkan qolbu. Dengan dzikir akan meningkatkan kesadaran qolbu mulai dari ghoflah (kondisi hati yang lalai, yaitu tidak mengingat Alloh), intibah (hati yang telah bangun dari tidurnya atau lalai), yahdoh (hati yang sadar), hudur (hati yang hadir, yaitu hadirnya hati ketika berdzikir), muroqobah (mengawasi, memperhatikan gerak gerik hati, yaitu hati yang sudah mampu memperhatikan siapa yang memperhatikannya), musyahadah (menyaksikan), muwajahah (bertemu), iman taqlid, iman ilmu, iman iyan, iman haq, iman hakekat dan pada

${ }^{22}$ Imam syuyuti, Hasiyah $s o>w i>$ 'ala $>$ tafsi $>$ r jala $>$ lain, Haromain, h. 44 
puncaknya menjadi manusia sempurna atau insan kamil. Ketika manusia sudah mencapoai insan kamil maka qolbnya akan menjadi tenang dan tidak mudah stress.

Berdasarkan paparan di atas dapat digambarkan peran tasawuf dalam mengelola stress, yaitu:

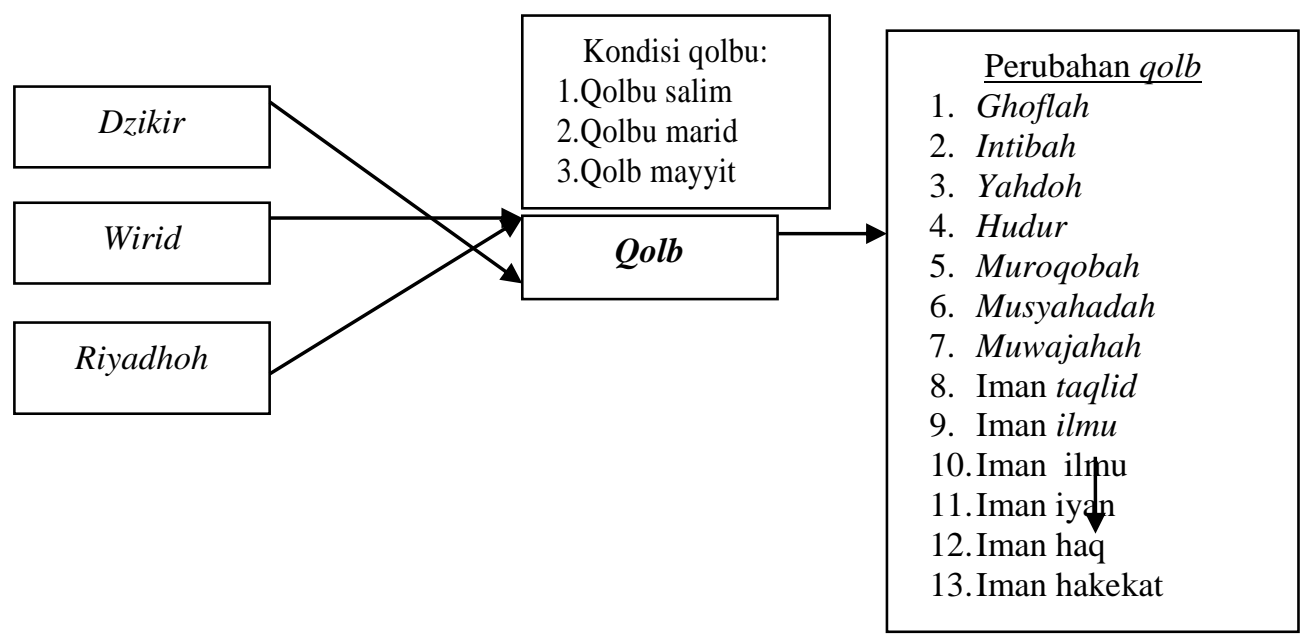

\section{E. Simpulan}

Eksistensi manusia yang terdiri dari jasmani dan rohani, mental dan spiritual yang satu sama lain harus memiliki balance dalam interaksi dengan lingkungan dimana ia berada. Kemampuan menyesuaikan diri dan mengontrol emosi dalam menyikapi berbagai problema kehidupan menjadikan manusia rentan pada gangguan mental seperti stres, cemas dan gelisah.

Kemajuan sains dan teknologi pada masyarakat modern dan munculnya pemahaman the death of god membuat manusia semakin jauh dari transedental keagamaan dan lingkungan sosial sehingga menggangap dirinya adalah real creator. Berlandaskan pada akal sebagai dewa penyelamat bagi dirinya menjadikan dirinya termasuk dalam kategori orang yang mengalami gangguan kesehatan mental (neurose dan pcychose).

Hadirnya konsep sufistik dalam memberikan solusi adalah dengan konsep takhalli, tahalli dan tajalli menjadi aspirin bagi jiwa manusia. Melalui dzikir dan wirid yang diberikan oleh seorang mursyid arif billah sehingga dzikir tersebut dapat memberi manfaat dan dapat menerangi batinnya, dari qolb yang ghoflah (kondisi hati yang lalai, yaitu tidak mengingat Alloh), intibah (hati yang telah bangun dari tidurnya atau lalai), yahdoh (hati yang sadar), hudur (hati yang hadir, yaitu hadirnya hati ketika berdzikir), muroqobah (mengawasi, memperhatikan gerak gerik hati, yaitu 
hati yang sudah mampu memperhatikan siapa yang memperhatikannya), musyahadah(menyaksikan), muwajahah (bertemu), iman taqlid, iman ilmu, iman iyan, iman haq, iman hakekat dan pada puncaknya menjadi manusia sempurna atau insan kamil. Manusia yang telah mengenal hakikat diri seorang hamba maka harus rela dan cinta pada ketentuan dari yang Maha Kuasa. Sufi dapat memberikan peranannya dalam menciptakan kesehatan mental menuju terciptanya pembinaan kesehatan mental lewat dunia pendidikan dan dakwah.

\section{REFERENSI}

A. Rivai Siregar, Tasawuf dari Sufisme Klasik ke Neosufisme, (Jakarta: Raja Grafindo Persada, 2000).

Achmad Syarif Hidayat, Riyadhoh dan Mujahadah, https:dokumenpemudatqn.blogspot.com/2012/06/mengenalriyadohriyadhah-dalam-tarekat.html, 06 April 2012

Fathullah Gulen, Kunci-Kunci Rahasia Sufi, (Jakarta: Raja Grafindo, 2001).

Harun Nasution, Filsafat dan Mistisme dalam Islam, (Jakarta: Bulan Bintang, 1989).

Hazri Adlany, et al, al-Qur'an Terjemah Indonesia (Jakarta: Sari Agung,2002)

Ibnu Athoilah, Syarah Al-Hikam, Haramain,

Ibnu Katsir, Tafsir Al-Qur'an Al-'Adzim, ter. Bahrun Abu Bakar, juz 21

(Bandung: SinarBaru Algesindo, 2004).

Ibnu Qayyim al-Jauziyyah, Keajaiban Hati, ter. Fadhli Bahri (Jakarta: Pustaka Azzam,2002).

Imam syuyuti, Hasiyah so $>$ wi $>$ 'ala $>$ tafsi $>$ r jala $>$ lain, Haromain,

Ismail Nawawi, Risalah Pembersih Jiwa: Terapi Prilaku Lahir \& Batin Dalam Perspektif Tasawuf (Surabaya: Karya Agung Surabaya, 2008) Muslim bin Al-Hajjaj, Shahih Muslim, Juz 8 (Beirut: Dar Al-Kutub, 1995).

Nasaruddin Umar, Wirid dan Warid, http://mediaindonesia.com/read/detail/109598-dari-wirid-ke-warid, di akses tanggal 14 Agustus $201817.00 \mathrm{pm}$.

Nurcholis Madjid, Ensiklopedi Islam Untuk Pelajar, jld. 2 (Jakarta: PT Ichtiar Baru van Hoeve, 1998).

Rizal Ibrahim, Menghadirkan Hati (Yogyakarta: Pustaka Sufi, 2003).

Said Abdul Azhim, Rahasia Kesucian Hati, ter. Ade Hidayat (Jakarta: Qultum Media, 2006), 1 Qultum Media, 2006).

Sukanto dan A. Dardiri Hasyim, Nafsiologi; Refleksi Analisis Tentang Diri dan Tingkah Laku Manusia, (Surabaya: Risalah Gusti, 1995).

Uwes al-Qorni, 60 penyakit hati, (Bandung: Remaja Rosdakarya, 1999). 